\title{
PENGGUNAAN MULTIMEDIA INTERAKTIF MELALUI METODE "SUGGESTOPEDIA" TERHADAP PENINGKATAN MOTIVASI BELAJAR SISWA DALAM PELAJARAN BAHASA INGGRIS
}

\author{
Yayah Pujasari, Wandi Wardiana Rahayu \\ Universitas Pendidikan Indonesia \\ pujasari@yahoo.com
}

\begin{abstract}
This study aims to determine the effect of the use of MMI (interactive multimedia) through the suggestopedia of student learning motivation in English lessons. The research approach used in this research is quantitative approach with Quasi Experimental Design research design with Nonequivalent Control Group Design model. The sample of this research is student X SMK AL HALIM Garut 2 class. The results showed that the results of multiple correlation test, it turns out (3.44 or 5.72) it can be stated that the double correlation is significant, meaning there is a significant relationship between the use of MMI through the method suggestopedia with learning motivation in English lessons. Result of second hypopenelitian test with t-test obtained value (9,212) (2,6933) and reside in area of acceptance hence Ho is rejected, meaning there are difference of learning motivation significant between student learn using MMI through method of suggestopedia with student learn by method Conventional in English lessons.
\end{abstract}

Keywords: Interactive Multimedia, Suggestopedia Methods and Learning Motivation

\begin{abstract}
Abstrak
Penelitian ini bertujuan untuk mengetahui pengaruh penggunaan MMI (interaktif multimedia) melalui Sugestopedia motivasi belajar siswa dalam pelajaran Bahasa Inggris. Pendekatan penelitian yang digunakan dalam penelitian ini adalah pendekatan kuantitatif dengan desain penelitian Quasi Experimental Design dengan model Nonequivalent Control Group Design. Sampel penelitian ini adalah siswa kelas X SMK AL HALIM Garut 2. Hasil penelitian menunjukkan bahwa hasil uji korelasi berganda, ternyata $(3,44$ atau 5,72) dapat dinyatakan bahwa korelasi ganda adalah signifikan, artinya ada hubungan yang signifikan antara penggunaan MMI melalui metode Sugestopedia dengan motivasi belajar dalam pelajaran bahasa Inggris. Hasil uji hipotesis kedua dengan t-test diperoleh nilai $(9,212)(2,6933)$ dan berada di area penerimaan maka Ho ditolak, artinya ada perbedaan motivasi belajar yang signifikan antara siswa yang belajar menggunakan MMI melalui metode Sugestopedia dengan siswa belajar dengan metode Konvensional dalam pelajaran bahasa Inggris.
\end{abstract}

Kata Kunci: Metode Suggestopedia, Motivasi Belajar, Multimedia Interaktif

\section{A. PENDAHULUAN}

Perkembangan teknologi pendidikan atau teknologi pembelajaran menghasilkan berbagai konsep dan praktik pendidikan yang banyak memanfaatkan media sebagai sumber belajar. Kedudukan teknologi dari segi sistem pendidikan berfungsi untuk memperkuat pengembangan kurikulum terutama dalam disain dan pengembangan, serta implementasinya. Teknologi pendidikan dalam proses pembelajaran 
bermanfaat untuk memperkuat dalam merekayasa berbagai cara dan teknik dari mulai tahap mendesain, pengembangan, pemanfaatan berbagai sumber belajar, implementasi, penilaian program, dan penilaian hasil belajar. Dengan kata lain, teknologi pendidikan atau teknologi pembelajaran lahir untuk mengatasi masalah yang ada dalam pembelajaran. Seperti yang berkaitan dengan motivasi belajar siswa atau hasil belajar siswa.

Hal ini sejalan dengan permasalahan dalam pembelajaran yang sering ditemukan apalagi dalam pelajaran Bahasa Inggris. Dalam pelajaran Bahasa Inggris, peserta didik banyak yang menganggap bahwa pelajaran Bahasa Inggris adalah pelajaran yang susah. Sehingga, anggapan itu secara otomatis akan menurunkan motivasi belajar siswa dan akan mempengaruhi hasil belajar siswa dalam pelajaran Bahasa Inggris dan pada akhirnya penyampaian informasi atau materi pembelajaran terhambat. Sedangkan Bahasa Inggris merupakan Bahasa internasional yang wajib di pelajari di Indonesia.

Goodlad (dalam Lang dan Evans 2006:343) mengemukakan bahwa "Students typically are passive, they just sit, listen, answer low question and are often getting bored". Kutipan tersebut mempertegas bahwa kebanyakan siswa mempunyai tipikal yang pasif, hanya mendengar, mereka hanya diam dan sering jenuh. Oleh karena itu, apabila kita hanya menggunakan metode pembelajaran klasik seperti ceramah, itu tidak cukup baik jika diterapkan dalam pembelajaran secara terus menerus. Dalam hal ini seorang guru harus mempunyai kemampuan Managing Class dengan baik.

1. Rumusan Masalah Penelitian

a. Adakah hubungan antara penggunaan MMI (multimedia interaktif) beserta penerapan metode suggestopedia dengan motivasi belajar dalam pelajaran Bahasa Inggris pada siswa kelas X SMK AL HALIM Garut?

b. Apakah terdapat perbedaan motivasi belajar antara siswa yang belajar menggunakan MMI (multimedia interaktif) beserta penerapan metode suggestopedia dengan siswa yang belajar dengan menggunakan metode konvensional?

2. Tujuan Penelitian

a. Untuk mengetahui hubungan antara penggunaan MMI (multimedia interaktif) beserta penerapan metode suggestopedia dengan motivasi belajar dalam pelajaran Bahasa Inggris pada siswa kelas X SMK AL HALIM Garut.

b. Untuk mengetahui perbedaan motivasi belajar siswa antara siswa yang belajar menggunakan MMI (multimedia interaktif) beserta penerapan metode suggestopedia dengan siswa yang belajar dengan menggunakan metode konvensional.

3. Hipotesis Penelitian

a. Terdapat hubungan yang signifikan antara penggunaan MMI (multimedia interaktif) beserta penerapan metode suggestopedia dengan motivasi belajar dalam pelajaran Bahasa Inggris pada siswa kelas X SMK AL HALIM Garut.

b. Terdapat perbedaan motivasi belajar yang signifikan antara siswa yang belajar menggunakan MMI (multimedia interaktif) beserta penerapan metode suggestopedia dengan siswa yang belajar dengan menggunakan metode konvensional dalam pelajaran Bahasa Inggris pada siswa kelas X SMK AL HALIM Garut. 


\section{B. KAJIAN LITERATUR}

Sebagaimana dinyatakan oleh peneliti pendidikan M.C. Reynolds (dalam Satori dkk, 2007: 2.33) menyatakan bahwa:

Seorang guru diharapkan berperan sebagai innovator atau agen perubahan maka guru perlu memiliki wawasan yang memadai mengenai berbagai inovasi dan teknologi pendidikan yang pernah dan mungkin dikembangkan pada jenjang pendidikan.

Oleh karena itu dalam penelitian ini, peneliti menggunakan model Multimedia Interaktif (MMI) dan menerapkan metode pembelajaran Bahasa Inggris yaitu Suggestopedia dengan cara menggunakan MMI dan menerapkanya metode tersebut dalam proses pembelajaran secara bersamaan menjadi pembelajaran yang menarik, effective, active dan innovative. Sebagaimana yang dikatakan oleh Peneliti Pendidikan Chisholm and Ely (dalam Winataputra dkk, 2007: 2.12) menyatakan bahwa:

Hasil penelitian di dunia pembelajaran menyatakan bahwa penggunaan media yang beragam (dua atau lebih) secara variatif menghasilkan dampak positif yang lebih tinggi dalam proses pembelajaran daripada media tunggal secara terus menerus.

Penggunaan model (MMI) dalam proses pembelajaran, khususnya pembelajaran Bahasa Inggris terasa masih kurang digunakan. Apalagi, digabungkan dengan metode pembelajaran Bahasa Inggris yang mempunyai karakteristik yang menarik, efektif, pengkondisian rilek seperti metode Suggestopedia. Model pembelajaran MMI merupakan kombinasi teks, gambar, grafik, suara, video, animasi, simulasi secara terpadu dan sinergis dengan bantuan aplikasi komputer tertentu yang digunakan untuk membantu siswa mencapai tujuan pembelajaran. Dalam proses pembelajaran dengan menggunakan MMI siswa dapat mengontrol dan beriteraksi secara dinamis, sehingga memungkinkan siswa atau pengguna untuk belajar mandiri. Di samping itu, penggunaan MMI mampu menarik minat belajar atau motivasi siswa dalam pembelajaran, baik secara mandiri atau kelompok.

Dalam ilmu bahasa, suggestopedia merupakan metode yang pernah menggebrak dunia pendidikan, memiliki keunggulan dalam hal pemanfaatan gelombang alpha dan gelombang betha dalam proses pembelajaran. Gelombang alpha dimanfaatkan untuk menanamkan suggestopediati pada siswa dan gelombang betha dimanfaatkan untuk menggairahkan siswa dalam kegiatan belajar. Suggestopediati tersebut ditanamkan melalui sumber audio.Di sinilah saat yang kuat antara suggestopedia dan menyimak terjadi. Suggestopedia dianggap sebagai "Magic method" dalam pembelajaran Bahasa.

Pada awalnya Suggestopedia dikembangkan oleh ahli psikologi yang berasal dari negara Bulgaria bernama Georgi Lozanov (2005). Lozanov percaya bahwa otak manusia mampu untuk memproses materi atau pelajaran dengan baik dan cepat jika diberikan pada kondisi yang tepat seperti rilek dan tenang.Untuk mendapatkan kondisi yang rilek di dalam kelas kita bisa mendekorasi kelas sesuai dengan keinginan siswa. Seperi yang dikatakan oleh Norland, Deborah and Terry (2006: 15) bahwa:

The most conspicuous characteristics of Suggestopedia are the decoration, furniture, and arrangement of the classroom, the 
use of music, and the authoritative behavior of the teacher. The characteristics of suggestopedia are kinds of tools to increase the student interest.

Ini menegaskan bahwa karakteristik dari suggestopedia adalah pengaturan ruang belajar atau kelas, menggunakan musik dan segala jenis peralatan yang bisa digunakan untuk menarik siswa dalam proses pembelajaran. Penataan dekorasi dan penggunaan jenis alat atau media apapun yang digunakan untuk meningkatkan motivasi siswa dalam belajar merupakan beberapa kelebihan atau keunggulan dari pada metode suggestopedia ini. Beberapa kelebihan yang lain di antaranya metode suggestopediatipedia ini menekankan kepada reading skill (kemampuan membaca) dan listening skill (kemampuan mendengar) khususnya dalam pelajaran Bahasa Inggris.

Sedangkan kelemahan atau kekurangan dari metode ini adalah metode ini kurang menekankan atau kurang memberikan kontribusi pada jenis kemampuan lain dalam Bahasa Inggris yaitu writing skill (kemampuan menulis) dan Speaking Skill (kemampuan berbicara). Hal ini ditegaskan oleh Norland, Deborah dan Terry (2006: 15) bahwa the method it does not address to speaking and writing, it is not communicative.

Penggunaan model MMI dan juga menerapkan Metode Pembelajaran Suggestopedia merupakan salah satu cara untuk meningkatkan motivasi siwa dalam proses pembelajaran. Motivasi merupakan salah satu faktor yang sangat dominan yang ikut menentukan tercapai atau tidaknya tujuan pendidikan. Pemberian motivasi yang dimaksud dalam belajar sebenarnya tidak lain daripada usaha yang dilakukan untuk membuat siswa agar "mau" atau "berkeinginan" untuk belajar sesuai dengan keinginan pihak guru atau pihak orangtua. Usaha memberi motivasi ini dilakukan dengan memanipulasi situasi dalam diri individu (internal) maupun situasi di luar diri individu (external) secara psikologis.

Berdasarkan pengamatan sementara di kelas X SMK AL Halim Garut ditemukan permasalahan bahwa banyak siswa menganggap bahwa pelajaran Bahasa Inggris merupakan pelajaran yang susah. Atas dasar anggapan tersebut secara otomatis akan menurunkan motivasi siswa dalam belajar Bahasa Inggris. Ini dibuktikan dengan kurang aktifnya siswa di SMK AL Halim Garut dalam proses pembelajaran Bahasa Inggris, sehingga banyak dari mereka mendapatkan nilai ulangan harian yang di bawah KKM. Dari pengamatan terkahir dalam ulangan harian, rata-rata nilai ulangan siswa adalah 65 sedangkan KKM nya adalah 70 . Hal ini ditambah dengan kurangnya penggunaan metode belajar dalam proses pembelajaran Bahasa Inggris, kebanyakan guru masih menngunakan metode belajar konvensional seperti speech (ceramah). Kemudian ditambah kurangnya penggunaan multimedia pembelajaran oleh guru dalam proses pembelajaran Bahasa Inggris.

\section{METODOLOGI PENELITIAN}

Metode penelitian yang akan dilaksanakan pada penelitian kali ini adalah metode penelitian kuantitatif. Dalam penelitian ini Peneliti bertujuan untuk menggunakan penelitian kuantitatif sebagai pedoman dan sumber yang akan dilaksanakan pada penelitian ini.

Dalam penelitian ini desain penelitianya menggunakan desain eksperimen dimana mengggunakan quasi experimental. Desain penelitian ini merupakan pengembangan dari true experimental design, yang sulit untuk dilaksanakan. Desain ini mempunyai kelompok kontrol, tetapi tidak dapat berfungsi sepenuhnya untuk mengontrol 
variabel-variabel luar yang mempengaruhi pelaksanaan eksperimen.

Dalam desain penelitian quasi experimental ada dua bentuk desain quasi experimental yaitu Time-Series Design dan Nonequevalent Control Group Design. Dalam hal ini penelitiakan menggunakan Nonequevalent Control Group Design. Desain ini hampirsama dengan pre-test sampai post-test control group design, hanya pada desain ini kelompok experiment maupun kontrol tidak dipilih secara random. Instrument penelitian yang digunakan dalam penelitian ini adalah berupa angket dengan 5 skala.

Kemudian untuk mengetahui perbedaan peningkatan motivasi belajar antara siswa yang belajar menggunakan MMI (multimedia interaktif) beserta penerapan metode suggestopedia dengan siswa yang belajar dengan menggunakan metode konvensional peneliti menggunakan uji hipotesis perbandingan dua sampel yang saling bebas. Menurut Sundayana (2014: 143) "dua sampel yang saling bebas harus terlebih dahulu diuji mengenai normalitas sebaran datanya". Dalam hal ini jika kedua kelompok yang dibandingkan berdistribusi normal, maka menggunakan uji $t$ (independent sample $t$ test); namun jika salah satu atau kedua kelompok tidak berdistri busi normal maka harus menggunakan uji statistika non parametric yaitu uji Mann Whitney.

\section{HASIL DAN PEMBAHASAN}

1. Pengaruh penggunaan MMI (multimedia interaktif) beserta penerapan metode suggestopedia terhadap motivasi belajar

Penggunaan MMI dalam pembelajaran bahasa Inggris bukan merupakan hal yang baru diterapakan dalam dunia pendidikan, namun untuk disekolah kami penggunaan MMI merupakan salah satu inovasi baru yang diterapkan dalam pembelajaran bahasa Inggris. Dalam penelitian ini penggunaan MMI bertujuan untuk membuat siswa lebih tertarik dalam pelajaran bahasa Inggris sehingga bisa meningkatkan motivasi belajar siswa tersebut.

Penggunaan MMI juga bertujuan untuk membiasakan siswa belajar secara mandiri dalam pelajaran bahasa Inggris. Dengan MMI siswa bisa belajar secara mandiri dan bisa mengatur atau mengkontrol program MMI tersebut secara lebih fleksibel dan secara tidak disadari mereka sedang belajar dalam keadaan yang senang dan tidak ada tekanan. Dalam penelitian ini selain menggunakan MMI peneliti juga menerapkan metode sugesstopedia secara bersamaan dengan MMI dalam pelajaran bahasa Inggris.

Karakteristik yang paling menonjol dari suggestopedia adalah pengaturan ruang belajar atau kelas, menggunakan musik dan segala jenis peralatan yang bisa digunakan untuk menarik siswa dalam proses pembelajaran. Penataan dekorasi dan penggunaan jenis alat atau media apapun yang digunakan untuk meningkatkan motivasi siswa dalam belajar merupakan beberapa kelebihan atau keunggulan dari pada metode suggestopedia ini.

Dalam penelitian ini, peneliti menerapkan metode suggestopedia sebagai salah satu sarana dimana siswa bisa menggunakan imajinasinya dalam pembelajaran bahasa Inggris. Siswa bisa menata ruangan dan tempat belajar sesuai kehendaknya sehingga akan menimbulkan kenyamanan atau suasana rilek dalam proses pembelajaran yang disajikan melalui MMI. Ketika siswa menggunakan MMI dalam kelas yang diterapkan metode suggestopedia, mereka akan bertambah rilek dengan penggunaan muzak atau instrument musik. Karena kelas yang nyaman dan materi yang disajikan dalam MMI tersebut menjadi nilai tambah 
motivasi siswa dalam proses pembelajaran bahasa Inggris dengan menggunakan MMI dan menerapkan metode suggestopedia secara bersama-sama.

Dalam penelitian ini, penggunaan MMI dan penerapan metode suggestopedia berpengaruh signifikan terhadap motivasi belajar siswa. Hal ini dibuktikan dengan hasil perhitungan korelasi ganda terhadap variabel X1 (MMI), X2(Suggestopedia) dengan variabel Y (Motivasi belajar). Dari perhitungan tersebut ternyata $F_{\text {hitung }}$ $(129,306)>F_{\text {tabel }}(3,44$ atau 5,72) maka dapat dinyatakan bahwa korelasi ganda tersebut signifikan.

Dari hasil tersebut dapat disimpulkan bahwa terdapat hubungan yang signifikan antara penggunaan MMI (multimedia interaktif) beserta penerapan metode suggestopedia dengan motivasi belajar dalam pelajaran Bahasa Inggris pada siswa kelas X SMK AL HALIM Garut. Dengan kata lain penggunaan MMI dan penerapan metode suggestopedia secara bersamasama dalam pelajaran bahasa Inggris sangat berpengaruh terhadap motivasi belajar siswa.

Seperti halnya dengan penelitian yang dilakukan oleh Chang dan Lehman pada musim gugur tahun 2000 yang berjudul Learning Foreign Language through an Interactive Multimedia Program. Dari penelitian tersebut didapatkan hasil penelitian bahwa penggunaan CBIM (computer-based interactive multimedia) mempunyai pengaruh terhadap peningkatan yang lebih tinggi motivasi intrinsik siswa. Kombinasi dari dua variabel memiliki lebih besar efek dari salah satu saja. Temuan ini menunjukkan bahwa kombinasi dari peningkatan motivasi intrinsik siswa dan strategi pembelajaran yang sesuai.

Dalam penelitian yang dilakukan oleh Chang dan Lehman (2002) mengkobinasikan penggunaan multimedia interaktif dengan strategi pembelajaran yang tepat. Dengan kata lain penggunaan multimedia interaktif harus di perhatikan mengenai strategi, pendekatan bahkan metode yang digunakan dalam proses penggunaan media tersebut. Sedangkan dalam penelitian yang dilakukan oleh peneliti kali ini, penggunaan multimedia dengan menerapkan metode suggestopedia menjadi suatu gabungan yang sangat baik, sehingga bisa mengoptimalkan peran dari MMI itu sendiri.

2. Perbedaan motivasi belajar antara siswa yang belajar menggunakan MMI (multimedia interaktif) beserta penerapan metode suggestopedia dengan siswa yang belajar dengan menggunakan metode konvensional

Motivasi belajar merupakan salah satu masalah umum yang ditemukan dalam proses pembelajaran. Apalagi dalam proses pembelajaran bahasa asing seperti pelajaran bahasa Inggris. Berbicara motivasi tidak terlepas dari psikologi, oleh karena erat kaitanya dengan keadaan atau situasi dimana manusia terpengaruhi oleh faktor lain. Apabila kaitanya dengan belajar maka jika ada siswa yang kurang termotivasi, maka ada sesuatu yang bertentangan dengan apa yang dia rasakan dan dia inginkan.

Bahkan menurut Luthans (dalam Pujadi, 2007: 42), "motivation is a process that starts with a physigological deficiency or need a drive that is aimed at a goal and incentive". Sehingga motivasi belajar dapat diartikan sebagai suatu proses yang diawali dengan keadaan psikologi dan kebutuhan yang mendorong seseorang untuk meraih suatu tujuan, dalam hal ini belajar.

Dalam penelitian ini, peneliti merasakan kurangnya motivasi dalam proses pembelajaran bahasa Inggris di 
SMK Al Halim Garut kelas X. Bahkan keadaan tersebut berpengaruh buruk terhadap hasil belajar siswa tersebut. Oleh karena itu, peneliti mencoba mengatasi permasalahan tersebut dengan menggunakan MMI (multimedia interaktif) dalam pelajaran bahasa Inggris. Bahkan untuk mengoptimalkan kinerja penggunaan MMI tersebut peneliti menerapkan metode suggestopedia secara bersamaan dengan MMI.

Untuk mengetahui perbedaan motivasi belajar siswa dalam pembelajaran bahasa Inggris dengan menggunakan MMI beserta penerapan metode suggestopedia secara bersamaan. Peneliti mengambil satu kelas sebagai kelas eksperimen dan satu kelas sebagai kelas kontrol. Pada kelas eksperimen diberikan pembelajaran dengan menggunakan MMI dan menerapkan metode suggestopedia secara bersamaan. Sedangkan, pada kelas kontrol diberikan pembelajaran bahasa Inggris dengan metode belajar konvensional.

Karena peneliti menggunakan desain penelitian Nonequevalent Control Group Design yaitu eksperimen terhadap dua kelompok, yang satu kelompoknya diberi perlakuan dan post-test, sedangkan pada kelompok lain hanya diberi post-test saja tidak ada pretest dan perlakuan. Oleh karena itu, peneliti tidak memberikan pretest baik dikelas eksperimen ataupun kelas kontrol. Setelah diberikan posttest dan diperoleh hasil data penelitianya bahwa terdapat perbedaan yang signifikan dari hasil data tersebut.

Hal ini terlihat pada rata-rata data hasil penelitian di kelas eksperimen sebesar (81) sedangkan di kelas kontrol diperoleh rata-rata sebesar (72). Dengan kata lain motivasi belajar siswa di kelas yang diberikan pembelajaran MMI dan penerapan metode suggestopedia lebih baik dari pada motivasi belajar siswa yang diberi metode konvensional. Kemudian untuk menjawab hipotesis penelitian tersebut peneliti melakukan uji t-test dan diperoleh $t_{\text {tabel }}$ sebesar $(2,6933)$. Dalam hal ini berlaku ketentuan Ho diterima jika $t_{\text {tabel }} \leq t_{\text {hitung }} \leq t_{\text {tabel }}$. Karena nilai $t_{\text {hitung }}$ $(9,212) \leq t_{\text {tabel }}(2,6933)$ dan berada pada daerah penerimaan Ha maka Ho ditolak dan Ha diterima.

Oleh karena itu dapat disimpulkan bahwa terdapat perbedaan motivasi belajar yang signifikan antara siswa yang belajar menggunakan MMI (multimedia interaktif) beserta penerapan metode suggestopedia dengan siswa yang belajar dengan menggunakan metode konvensional dalam pelajaran Bahasa Inggris. Dalam hal ini, motivasi belajar siswa yang diberikan pembelajaran bahasa Inggris dengan menggunakan MMI dan penerapan Suggestopedia lebih tinggi daripada siswa yang belajar bahasa Inggris dengan metode konvensional.

Seperti halnya dengan penelitian yang dilakukan oleh Leow dan Neo (2014), bahwa penerapan multimedia di Universitas International Malaysia mampu meningkatkan motivasi belajar mahasiswanya. Hal tersebut dibuktikan bahwa ada $77,4 \%$ dari seluruh siswa yang terlibat dalam penelitian tersebut sepakat bahwa mereka telah memiliki pengalaman yang baik untuk belajar dengan Interactive Learning Module tersebut yang pada dasarnya seperti Multimedia Interaktif, dan ada $74,2 \%$ dari mereka lebih memilih untuk melanjutkan dan merekomendasikan penerapan ILM ini untuk rekan mereka dan bisa diterapkan di kelas mereka. Di sisi lain, $83,9 \%$ siswa setuju bahwa merekatermotivasi untuk belajar dengan menggunakan ILM dan 74,2\% dari mereka setuju bahwa perhatian mereka meningkat dengan menggunakan ILM.

Dari penelitian yang dilakukan oleh Leow dan Neo (2014) bahwa lebih dari $75 \%$ dari seluruh siswa merasakan 
pengalaman yang berbeda dalam proses pembelajaran dalam hal ini pengalaman yang baik. Sehingga, mereka lebih memilih untuk terus menggunakan multimedia interaktif dalam proses pembelajaran. Hal yang sama dirasakan pada penelitian ini, dimana siswa yang diberikan pembelajaran MMI dan penerapan suggestopedia motivasi belajar mereka lebih tinggi daripada mereka yang hanya menggunakan metode konvensional. Karena pada dasarnya proses pembelajaran merupakan suatu kegiatan dimana melibatkan pengalaman siswa. Sehingga, terjadi perubahan pengalaman siswa dalam hal ini kearah yang lebih baik.

Dalam penelitian ini, salah satu bukti bahwa pengalaman belajar yang diberikan kepada siswa secara beragam (menggunakan MMI dan menerapkan metode suggestopedia) memberikan pengaruh yang sangat baik terhadap motivasi belajar siswa. Oleh karena itu, peneliti merekomendasikan bahwa penggunaan multimedia interaktif harus dioptimalkan atau disesuaikan dengan pendekatan, strategi bahkan metode pembelajaran yang tepat. Sehingga, pada akhirnya tercipta suatu pengalaman belajar yang bermakna bagi siswa, dan secara tidak disadari siswa akan lebih termotivasi dalam belajar. Temuan ini selaras dengan upaya meningkatkan kecepatan analisis dan sitesis terhadap kalimat bahasa inggris yang sedang dipelajari. Sebagaimana yang dikemukakan oleh Darmawan, dkk (2017:229) yang menjelasakan temuannya mengenai peserta didik yang mempelajari eks dijelaskan bahwa "...when the students perform the learning activity of understanding information presented during information technology-based learning, particularly when they restate the text that they have understood."

\section{E. SIMPULAN DAN SARAN}

1. Simpulan

Penggunaan MMI (multimedia interaktif) dan penerapan metode suggestopedia dalam pelajaran bahasa Inggris di SMK Al Halim Garut menjadi salah satu cara mengatasi permasalahan pembelajaran, salah satunya motivasi belajar siswa. Dalam hal ini, penggunaan MMI (multimedia interaktif) dan penerapan metode suggestopedia memberi dampak positif terhadap pengalaman belajar siswa dan secara tidak disadari memberikan perbedaan motivasi belajar menjadi lebih baik.

Bahkan dari hasil penelitian ini, dapat ditarik kesimpulan bahwa pertama; Terdapat hubungan yang signifikan antara penggunaan MMI (multimedia interaktif) beserta penerapan metode suggestopedia dengan motivasi belajar dalam pelajaran Bahasa Inggris pada siswa kelas X SMK AL HALIM Garut. Dengan kata lain penggunaan MMI dan penerapan metode suggestopedia secara bersama-sama dalam pelajaran bahasa Inggris sangat berpengaruh terhadap motivasi belajar siswa menjadi lebih baik.

Kedua; terdapat perbedaan motivasi belajar yang signifikan antara siswa yang belajar menggunakan MMI (multimedia interaktif) beserta penerapan metode suggestopedia dengan siswa yang belajar dengan menggunakan metode konvensional dalam pelajaran Bahasa Inggris. Dalam hal ini, motivasi belajar siswa dalam pembelajaran bahasa Inggris dengan menggunakan MMI dan penerapan Suggestopedia lebih baik daripada siswa yang belajar bahasa Inggris dengan metode konvensional.

2. Rekomendasi

Berdasarkan kesimpulan yang telah diperoleh, maka peneliti mengajukan beberapa rekomendasi baik untuk 
pembaca, guru, pengembang multimedia pembelajaran ataupun peneliti lainnya sebagai berikut: pertama; pengunaan media atau multimedia interaktif pembelajaran bahkan software pembelajaran dalam proses pembelajaran bahasa Inggris merupakan salah satu cara untuk mengatasi permasalahan dalam proses pembelajaran, kedua; penggunaan multimedia interaktif harus dioptimalkan atau disesuaikan dengan pendekatan, strategi bahkan metode pembelajaran yang tepat. Sehingga, pada akhirnya tercipta suatu pengalaman belajar yang bermakna bagi siswa, dan secara tidak disadari siswa akan lebih termotivasi dalam belajar.

Ketiga; dalam proses pembelajaran bahasa Inggris kita sebagai guru harus berusaha memaksimalkan imajinasi siswa dalam proses pembelajaran dengan cara memberikan pengalaman yang bermakna dalam proses pembelajaran, dan terakhir; peneliti berharap penelitian ini bisa dijadikan bahan perbandingan dan memberikan inspirasi untuk melakukan penelitian yang lebih baik mengenai peran teknologi pembelajaran dalam proses pembelajaran, sehingga tercipta lingkungan pembelajaran yang bermakna bagi siswa dan dapat meningkatkan motivasi belajar siswa bahkan hasil belajar siswa.

\section{DAFTAR PUSTAKA}

BSNP. (2006). Standar Isi untuk Satuan Pendidikan Dasar dan Menengah: Standar Kompetensi dan Kompetensi Dasar SMA/SMK. Jakarta. BSNP.

Darmawan, D., Ruyadi. Y., Abduh, Z.A., Hufad, A. (2017). Efforts to Know the Rate at which Students Analyze and Synthesize Information in Science and Social Science Disciplines: A Multidisciplinary Bio
Communication Study. [Online] Journal of Biological Sciences. 17 (3): 226.231. DOI: 10.3844/ojbsci. 2017.226.231.

Lang, Helmut R and Evans, David N. (2006). Models, Strategies, and Methods: for Effective Teaching. USA. Pearson Education.

Leow, F.T dan Neo, M. (2014). "Interactive Multimedia Learning: Innovating Classroom". The Turkish Online Journal of Educational Technology April 2014, volume 13 issue 2.

Lozanov, G. (2005). Suggestopaedia Desuggestive Teaching Communicative Method on the Level of the Hidden Reserves of the Human Mind. Vienna.

Norland, Deborah L and Terry. (2006). A Kaleidoscope of Models and Strategies for Teaching English to Speakers of Other Languages. USA. Libraries Unlimited.

Pujadi, Arko. (2007). "Faktor-faktor yang Mempengaruhi Motivasi Belajar Mahasiswa: Studi Kasus pada Fakultas Ekonomi Universitas Bunda Mulia". Dalam Business \& Management Journal Bunda Mulia vol. 3 (2), 12 .

Satori, D. at al. (2007). Propesi Keguruan. Jakarta. Universitas Terbuka.

Sundayana, R. (2014). Statistika Penelitian Pendidikan. Bandung. Alfabeta. 